КРАТКИЕ СООБЩЕНИЯ

УДК 550.8:528.94+552.1 (470.324)

ISSN 1609-0691

DOI: https://doi.org/10.17308/geology.2020.4/3130

Поступила в редакцию: 13.09.2020

Принята к публикации: 01.12.2020

Опубликована онлайн: 18.12 .2020

\title{
Петроплотностная карта докембрийского фундамента Воронежского кристаллического массива
}

\author{
(С2020 О. М. Муравина ${ }^{\bowtie}$, В.И. Жаворонкин \\ Воронежский государственный университет, \\ Университетская пл., 1, 394018, Воронеж, Российская Федерация
}

\begin{abstract}
Аннотация
Введение: В статье представлена вышедшая в июле 2020 г. в издательстве «Научный мир» Петроплотностная карта докембрийского фундамента Воронежского кристаллического массива масштаба $1: 1000000$ и объяснительная записка к ней. В комплект Петроплотностной карты входит компакт-диск с полным объёмом авторских материалов.

Методика: В работе над созданием карты участвовал коллектив авторов - сотрудников геологического факультета Воронежского госуниверситета: Глазнев В. Н., Муравина О. М., Жаворонкин В. И., Лебедев И. П., Воронова Т. А.. Карта является итогом многолетнего труда по обобщению и анализу данных о плотностных свойствах структурно-вещественных комплексов докембрийского фундамента Воронежского кристаллического массива.

Обсуждение результатов: В объяснительной записке карте даётся описание плотностных свойств структурно-вещественных геологических комплексов докембрийского фундамента Воронежского кристаллического массива центральной части Восточно-Европейской платформы. Приведены генерализованные сведения об изученности пород фундамента, его геологии, тектонике, дана характеристика осадочного чехла. Дано систематическое описание плотностных свойств пород фундамента территории исследований и рассмотрены закономерности связей петрофизических характеристик пород с наблюдаемыми геофизическими полями, а также корреляции значений плотности с другими петрофизическими данными.

Bblвoдbl: Результативная модель плотности кристаллического фундамента Воронежского массива раскрывает новые возможности интерпретации гравитационных аномалий и построения трёхмерных плотностных моделей региона в различных масштабах. Петроплотностная карта и объяснительная записка к ней будут полезны в качестве учебного пособия по специальным разделам курса петрофизики и интерпретации потенциальных полей на уровне магистратуры и аспирантуры. Акцент на практические возможности использования петроплотностных данных представляет интерес для геофизиков и геологов производственных организаций.
\end{abstract}

Ключевые слова: петроплотностная карта, Воронежский кристаллический массив, петрофизика, гравитационное поле

Источник финансирования: работа выполнена при поддержке грантов РФФИ 18-05-00226 А, 19-0500336 A, 20-05-00190 A

Для цичтирования: Муравина О. М., Жаворонкин В. И. Петроплотностная карта докембрийского фундамента Воронежского кристаллического массива // Вестник Воронежского государственного университета. Серия: Геология. 2020. №. С. 81-86. DOI: https://doi.org/10.17308/geology.2020.4/3130

The content is available under Creative Commons Attribution 4.0 License.

\footnotetext{
${ }^{\square}$ Муравина Ольга Михайловна, e-mail: muravina@geol.vsu.ru
} 


\section{Введение}

В июле 2020 г. в издательстве «Научный мир» вышла Петроплотностная карта докембрийского фундамента Воронежского кристаллического массива масштаба $1: 1000000$ и объяснительная записка к ней [1]. В комплект Петроплотностной карты входит компактдиск с полным объёмом авторских материалов. В работе над созданием карты участвовал коллектив авторов - сотрудников геологического факультета Воронежского госуниверситета: Глазнев В. Н., Муравина О. М., Жаворонкин В. И., Лебедев И. П., Воронова Т. А. Петроплотностная карта - это результат планомерного обобщения многолетних исследований, выполненных силами производственных геологоразведочных и научных организаций, по изучению физических свойств пород Воронежского кристаллического массива (ВКМ). Работа базируется на первичных данных петрофизических измерений за почти вековой период, представленных в геологических отчётах и открытых публикациях, а также на материалах, полученных авторами издания. Объём использованной первичной информации является уникальным по своему охвату и включает данные по образцам пород из керна около 4500 скважин, пробуренных в разные годы на территории ВКМ. Для создания сводной базы петрофизических данных были использованы более 70000 лабораторных измерений физических свойств горных пород. Петроплотностная карта докембрийского фундамента Воронежского кристаллического массива сформирована на принципиально новом уровне, поскольку опирается на пространственную привязку петрофизических данных в среде ГИС ArcView и на геологическую карту ВКМ масштаба 1 : 500000 [2]. Вариации плотности всех геологических комплексов ВКМ подробно охарактеризованы статистическими параметрами, оценки которых представлены в «Петроплотностной карте». Реализованный подход является наиболее оптимальным в условиях неоднородной сети скважин и неравномерного представительства пород по глубине отбора керна. В процессе формирования карты была обоснована и опробована оригинальная технология обработки и классификации первичных петроплотностных данных, которая отражены в объяснительной записке [3-9]. Работа по формированию карты продолжалась не один год, и на протяжении этого времени результаты исследований последовательно представлены в ведущих российских и зарубежных научных журналах [3-13].

\section{Содержание объяснительной записки}

Первая часть монографии посвящена геологической характеристике докембрийских образований ВКМ по данным обширного перечня цитируемых публикаций [14-17], в которых даны наиболее полные региональные обзоры геологического строения, тектоники и геохронологии кристаллического фундамента изучаемой территории.

Во второй части объяснительной записки описаны источники фактических данных о плотности пород.
Исходными данными для создания модели плотности кристаллических пород фундамента послужили материалы лабораторных измерений физических свойств по образцам керна разведочных и поисковых скважин, пробуренных в разные годы различными геологоразведочными организациями, плановое положение которых показано на карте (вкладка «Схематическая карта глубин фундамента») [1]. Общее количество опробованных образцов керна осадочных и кристаллических пород достигает 150000. За последнее десятилетие в петрофизической лаборатории ВГУ выполнено ещё более 7000 измерений петрофизических свойств пространственно привязанных образцов кристаллических и осадочных пород региона ВКМ и прилегающих территорий.

Сложность геологического строения объекта исследования и большой объем разнородной первичной петрофизической информации определили необходимость формирования базы пространственных петрофизических данных. Основные принципы и методика создания базы данных, отражённые в публикациях авторов $[3,4,9,10]$, изложены в третьей части работы. На основе сформированных методических подходов в четвёртом разделе приведены результаты статистического анализа петроплотностных данных, которые проиллюстрированы соответствующими графиками и диаграммами.

В пятом разделе описывается методика обработки и обобщения пространственных данных о плотности горных пород региона и принципы построения карты. Построение петроплотностной карты фундамента ВКМ выполнено стандартными средствами ГИС ArcView 3.2 в виде картографической компоновки в географических координатах (вкладка «Петроплотностная карта докембрийского фундамента») [1]. Цветовая шкала графического представление петроплотностных данных была определена параметрами идентификационного анализа материалов измерений для петротипов [3, 4, 8-10], так чтобы достоверно выявлять значимые различия в плотностных характеристиках комплексов и отдельных объектов.

Построение петроплотностной модели кристаллического фундамента изучаемой территории изначально было нацелено на создание содержательного физического приближения верхней части кристаллической коры региона [18], предназначенного для последующей интерпретации аномального гравитационного поля ВКМ на основе развитых авторских подходов [19-21]. Важные аспекты таких интерпретационных построений рассматриваются в шестом разделе, посвященном комплексному анализу физические свойств и геофизических полей региона [21]. Петроплотностные характеристики пород докембрийского фундамента ВКМ сопоставлены с гравитационным и магнитным полями региона. В результате интерпретационных построений выявлены особенности соотношений геофизических полей, петрофизических свойств геологических комплексов и особенности строения земной коры региона исследований [18-23]. 


\section{Заключение}

Результативная модель плотности кристаллического фундамента Воронежского массива раскрывает новые возможности интерпретации гравитационных аномалий и построения трёхмерных плотностных моделей региона в различных масштабах. Монография будет полезна в качестве учебного пособия по специальным разделам курса петрофизики и интерпретации потенциальных полей на уровне магистратуры и аспирантуры. Акцент на практические возможности использования петроплотностных данных представляет интерес для геофизиков и геологов производственных организаций.

Исследование было поддержано грантами РФФИ №№ 18-05-00226, 19-05-00336, 20-05-00190.

Конфликт интересов: Авторы декларируют отсутствие явных и потенциальных конфликтов интересов, связанных с публикацией настоящей статьи

\section{ЛИТЕРАТУРА}

1. Глазнев В. Н., Муравина О. М., Жаворонкин В. И., Лебедев И. П., Воронова Т. А. Петроплотностная карта докембрийского фундамента Воронежского кристаллического массива, Воронеж, 2020. $101 \mathrm{c.}$

2. Молотков С. П., Костюков В. И., Лосицкий В. И. Кривцов И. И., Золототрубова Э. И., Пономарёва Р. Н. Геологическая карта Воронежского кристаллического массива масштаба 1 : 500000 / Министерство природных ресурсов РФ, ГПП “Воронежгеология", ОАО “Белгородгеология", ВГУ, НКПР "Хорс". Воронеж, 1999.

3. Глазнев В. Н., Минц М. В., Муравина О. М. Плотностное моделирование земной коры центральной части ВосточноЕвропейской платформы // Вестник КРАУНЦ. Науки о Земле. 2016. Вып. 29. № 1. С. 53-63.

4. Muravina O. M., Glaznev V. N., Mints M. V. 3D-density Model of the Earth Crust for Central part of the East-European Platform / Surface waves propagating in the geophysical environment "Lithosphere - Hydrosphere - Ice Cover - Atmosphere". 2018. C. $81-86$.

5. Муравина О. М. Метод группового учёта аргументов при анализе геофизических данных // Геофизика. 2012. № 6. C. $16-20$.

6. Муравина О. М., Пономоренко И. А. Программная реализация метода группового учёта аргументов при идентификационном моделировании геолого-геофизических данных // Вестник Воронежского государственного университета. Серия: Геология. 2016. № 2. С. 107-110.

7. Муравина О. М. Идентификационный анализ петрофизических характеристик пород осадочного чехла Воронежской антеклизы // Вестник КРАУНЦ. Серия: Науки о Земле. 2013. № 2 (22). C. 20-25.

8. Муравина О. М., Жаворонкин В. И., Глазнев В. Н. Петрофизическая характеристика осадочного чехла Воронежской антеклизы // Вестник Воронежского государственного университета. Серия: Геология. 2013. №1. С. 189-196.

9. Муравина О. М., Жаворонкин В. И. Статистический анализ цифровой основы петроплотностной карты Воронежского кристаллического массива // Вестник Воронежского государственного университета. Серия: Геология. 2015. № 2. С. 94-99.

10. Muravina O. M., Davudova E. I., Ponomarenko I. A. Possibility of Identification of Modeling in Complex Analysis Geological and Geophysical Data / Springer Proceedings in Earth and Environmental Sciences: Practical and Theoretical Aspects of
Geological Interpretation of Gravitational, Magnetic and Electric Fields. Eds. D.Nurgaliev, N.Khairullina. Springer Nature Switzerland AG, 2019. P. 57-162.

11. Антонов Ю. В., Жаворонкин В. И., Муравина О. М., Слюсарев С. В. Плотностная модель литосферы Воронежского кристаллического массива вдоль профиля Рыльск - Борисоглебск // Вестник Воронежского государственного университета. Серия: Геология. 1999. № 7. С. 187-195.

12. Антонов Ю. В., Муравина О. М., Иванова Н. Ю. Решение обратной задачи гравиразведки при объёмном моделировании // Вестник Воронежского государственного университета. Серия: Геология. 2007. № 1. С. 141-145.

13. Muravina O. M., Glaznev V. N., Zhavoronkin V. I., Mints M.V. Reflection of the Petrophysical Basement Rocks Models in Geophysical Fields / Springer Proceedings in Earth and Environmental Sciences: Practical and Theoretical Aspects of Geological Interpretation of Gravitational, Magnetic and Electric Fields. Springer Nature Switzerland AG, 2019. P. 49-54.

14. Чернышов Н. М., Ненахов В. М., Лебедев И. П., Стрик Ю. Н. Модель геодинамического развития Воронежского массива в раннем докембрии // Геотектоника. 1997. № 3. С. 21-30. 15. Чернышов Н. М. (Ред.) Литосфера Воронежского кристаллического массива по геофизическим и петрофизическим данным / Воронеж: Научная книга, 2012. 330 с.

16. Савко А. Д., Мануковский С. В., Мизин А. И., Бурыкин В. Н., Бартенев В. К., Окороков В. А., Бабкин В. Ф. Литология и фации донеогеновых отложений Воронежской антеклизы. Труды научно-исследовательского института геологии: Воронеж, Изд-во Воронеж. гос. ун-та. Вып. 3. 2001. 201 с.

17. Савко К. А., Самсонов А. В., Холин В. М., Базиков Н. С. Мегаблок Сарматия как осколок суперкратона Ваалбара: корреляция геологических событий на границе архея и палеопротерозоя // Стратиграфия. Геологическая корреляция. 2017. T. 25. № 2. C. 3-26.

18. Глазнев В. Н., Муравина О. М., Воронова Т. А., Холин В. М. Оценка мощности гравиактивного слоя земной коры Воронежского кристаллического массива // Вестник Воронежского государственного университета. Серия: Геология. 2014. № 4. С.78-84.

19. Воронова Т.А., Муравина О.М. Детальное плотностное моделирование верхней части Воронежского кристаллического массива // Вестник Воронежского государственного университета. Серия: Геология. 2014. № 2. С. 150-154.

20. Муравина О.М. Плотностная модель земной коры Воронежского кристаллического массива // Вестник Воронежского государственного университета. Серия: Геология. 2016. № 1. C. $108-114$.

21. Минц М. В., Глазнев В. Н., Муравина О. М. Глубинное строение коры юго-востока Воронежского кристаллического массива по геофизическим данным: геодинамическая эволюция в палеопротерозое и современное состояние коры // Вестник Воронежского государственного университета. Серия Геология. 2017. № 4. С. 5-23.

22. Глазнев В. Н., Жаворонкин В. И., Муравина О. М., Антонова И. Ю., Воронова Т. А., Черешинский А. В., Холин П. В. Строение верхней коры Елецкого участка Лосевского террейна (Воронежский кристаллический массив) по данным плотностного моделирования // Вестник Воронежского государственного университета. Серия: Геология. 2019. №3. С. 74-83.

23. Voronova T. A., Glaznev V. N., Muravina O. M., Antonova I. Y. The Density Model of the Crystalline Crust the Southwestern Part of the Lipetsk Region / Springer Proceedings in Earth and Environmental Sciences: Practical and Theoretical Aspects of Geological Interpretation of Gravitational, Magnetic and Electric Fields. Eds. D. Nurgaliev, N. Khairullina. Springer Nature Switzerland AG, 2019. P. 69-76. 
Received: 13.09 .2020

Accepted: 01.12.2020

Published online: 18.12 .2020

\title{
Petrodensity map of the Precambrian basement of the Voronezh crystalline massif
}

\author{
(C) 2020 O. M. Muravina ${ }^{\bowtie}$, V. I. Zhavoronkin \\ Voronezh State University \\ 1 Universitetskaya pl., Voronezh 394018, Russian Federation
}

\begin{abstract}
Introduction: The article presents a petrodensity map of the Precambrian basement of the Voronezh crystalline massif (scale of 1: 1,000,000) together with an explanatory note, published in July 2020 by the Scientific World publishing house. A CD with all the materials collected by the authors is provided together with the map.

Methodology: The map was designed by a team of researchers from the Faculty of Geology of Voronezh State University, including Glaznev V. N., Muravina O. M., Zhavoronkin V. I., Lebedev I. P., and Voronova T. A. The map is the result of many years of work on the generalization and analysis of data on the density properties of the structural and compositional complexes of the Precambrian basement of the Voronezh crystalline massif.

Results and Discussion: The explanatory note describes the density properties of the structural and compositional geological complexes of the Precambrian basement of the Voronezh crystalline massif located in the central part of the East European Platform. It also provides general information about the previous studies of the basement rocks, their geology, and tectonics. The characteristics of the sedimentary cover are given. The note also provides a systematic description of the density properties of the basement rocks in the studied area and describes the regularities of relationships between the petrophysical characteristics of the rocks and the observed geophysical fields, as well as the correlation between the density values and other petrophysical properties.

Conclusions: An effective model of the density of the crystalline basement of the Voronezh massif enables new interpretations of the gravity anomalies and the construction of three-dimensional density models of the region at various scales. The map and the explanatory note can be used as a teaching aid for specific sections of the course in petrophysics and interpretation of potential fields included in the master's and graduate degree programmes. The emphasis on the practical applications of the petrodensity data means that it can be of interest to geophysicists and geologists employed at industrial enterprises.
\end{abstract}

Keywords: petrodensity map, Voronezh crystalline massif, petrophysics, gravitational field.

Funding: The study was supported by grants of the Russian Foundation for Basic Research no. 18-0500226 A, 19-05-00336 A, and 20-05-00190 A.

For citation: Muravina O. M., Zhavoronkin V. I. Petrodensity map of the Precambrian basement of the Voronezh crystalline massif. Vestnik Voronezhskogo gosudarstvennogo universiteta. Seriya: Geologiya = Proceedings of Voronezh State University. Series: Geology, 2020, no. 4, pp. 81-86. DOI: https://doi.org/10.17308/geology.2020.4/3130

Conflict of interests: The authors declare the absence of obvious and potential conflicts of interest related to the publication of this article.

The content is available under Creative Commons Attribution 4.0 License.

${ }^{凶}$ Olga M. Muravina, e-mail: muravina@geol.vsu.ru 


\section{REFERENCES}

1. Glaznev V. N., Muravina O. M., Zhavoronkin V. I., Lebedev I. P., Voronova T. A. Petroplotnostnaya karta dokembrijskogo fundamenta Voronezhskogo kristallicheskogo massiva [Petrodensity map of the precambrian basement of the Voronezh crystalline massif], Voronezh, 2020. 101 p. (in Russ.).

2. Molotkov S. P., Kostyukov V. I., Losickij V.I . Krivcov I. I., Zolototrubova E. I., Ponomaryova R. N. Geologicheskaya karta Voronezhskogo kristallicheskogo massiva masshtaba 1: 500000. Ministerstvo prirodnyh resursov RF, GPP "Voronezhgeologiya", OAO "Belgorodgeologiya", VGU, NKPR "Hors". Voronezh, 1999. (in Russ.).

3. Glaznev V. N., Minc M. V., Muravina O. M. Plotnostnoe modelirovanie zemnoj kory central'noj chasti Vostochno-Evropejskoj platformy [Density modelling of the earth crust for central part of the East-European platform]. Vestnik KRAUNC. Nauki o Zemle, 2016, no. 1(29), pp. 53-63. (in Russ.).

4. Muravina O. M., Glaznev V. N., Mints M. V. 3D-density Model of the Earth Crust for Central part of the East-European Platform. Surface waves propagating in the geophysical environment "Lithosphere - Hydrosphere - Ice Cover - Atmosphere". 2018, pp. 81-86.

5. Muravina O. M. Metod gruppovogo ucheta argumentov pri analize geofizicheskih dannyh [The method of group accounting of arguments in the analysis of geophysical data]. Geophysics, 2012, no. 6, pp. 10-20. (in Russ.).

6. Muravina O. M., Ponomarenko I. A. Programmnaya realizaciya metoda gruppo-vogo ucheta argumentov pri identifikacionnom modelirovanii geologo-geofizicheskih dannyh [Software implementation of the method of group accounting of arguments in identification modeling of geological and geophysical data]. Vestnik Voronezhskogo gosudarstvennogo universiteta. Seriya: Geologiya $=$ Proceedings of Voronezh State University. Series: Geology, 2016, no. 2, pp. 107-110. (in Russ.).

7. Muravina O. M. Identifikacionnyj analiz petrofizicheskih harakteristik porod osadochnogo chekhla Voronezhskoj anteklizy [Identification analysis of petrophysical characteristics of rocks of the sedimentary cover of the Voronezh anteclise]. Vestnik KRAUNC. Seriya: Nauki o Zemle, 2013, no. 2 (22), pp. 20-25. (in Russ.).

8. Muravina O. M., Zhavoronkin V. I., Glaznev V. N. Petrofizicheskaya harakteristika osadochnogo chekhla Voronezhskoj anteklizy [Petrophysical characteristics of the sedimentary cover of the Voronezh anteclise]. Vestnik Voronezhskogo gosudarstvennogo universiteta. Seriya: Geologiya $=$ Proceedings of Voronezh State University. Series: Geology, 2013, no. 1, pp. 189-196. (in Russ.).

9. Muravina O. M., Zhavoronkin V. I. Statisticheskij analiz cifrovoj osnovy petroplotnostnoj karty Voronezhskogo kristallicheskogo massiva [Statistical analysis of the digital basis of the petro-density map of the Voronezh crystalline massif]. Vestnik Voronezhskogo gosudarstvennogo universiteta. Seriya: Geologiya $=$ Proceedings of Voronezh State University. Series: Geology, 2015, no. 2, pp. 94-99. (in Russ.).

10. Muravina O. M. Davudova E. A., Ponomarenko I. A. Possibility of identification of modeling in complex analysis geological and geophysical data. Practical and Theoretical Aspects of Geological Interpretation of Gravitational, Magnetic and Electric Fields: proceedings of the 45th Uspensky International Geophysical Seminar. Ser. "Springer Proceedings in Earth and Environmental Sciences". 2019, pp. 157-162.

11. Antonov Yu. V., Zhavoronkin V. I., Muravina O. M., Slyusarev S. V. Plotnostnaya model' litosfery Voronezhskogo kristallicheskogo massiva vdol' profilya Ryl'sk - Borisoglebsk [Density model of the lithosphere of the Voronezh crystalline massif along the Rylsk - Borisoglebsk profile]. Vestnik Voronezh- skogo gosudarstvennogo universiteta. Seriya: Geologiya $=$ Proceedings of Voronezh State University. Series: Geology, 1999, no. 7, pp. 187-195. (in Russ.).

12. Antonov Yu. V., Muravina O. M., Ivanova N. Yu. Reshenie obratnoj zadachi gravirazvedki pri ob"yomnom modelirovanii [Solution of the inverse problem of gravity prospecting in volumetric modeling]. Vestnik Voronezhskogo gosudarstvennogo universiteta. Seriya: Geologiya = Proceedings of Voronezh State University. Series: Geology, 2007, no. 1, pp. 141-145. (in Russ.). 13. Muravina O. M., Glaznev V. N., Zhavoronkin V. I., Mints M. V. Reflection of the Petrophysical Basement Rocks Models in Geophysical Fields / Springer Proceedings in Earth and Environmental Sciences: Practical and Theoretical Aspects of Geological Interpretation of Gravitational, Magnetic and Electric Fields. Springer Nature Switzerland AG, 2019, pp. 49-54.

14. Chernyshov N. M., Nenahov V. M., Lebedev I. P., Strik Yu. N. Model' geodinamicheskogo razvitiya Voronezhskogo massiva v rannem dokembrii [Model of Geodynamic Development of the Voronezh Massif in the Early Precambrian]. Geotektonika. 1997, no. 3, pp. 21-30. (in Russ.).

15. Chernyshov N. M. (Red.) Litosfera Voronezhskogo kristallicheskogo massiva po geofizicheskim i petrofizicheskim dannym [Lithosphere of the Voronezh Crystalline Massif according to geophysical and petrophysical data]. Voronezh, Nauchnaya kniga publ., 2012, 330 p. (in Russ.)

16. Savko A. D., Manukovsky S. V., Mizin A. I., Burykin V. N., Bartenev V. K., Okorokov V. A., Babkin V. F. Litologiya i facii doneogenovyh otlozhenij Voronezhskoj anteklizy [Lithology and facies of pre-Neogene deposits of the Voronezh anteclise]. Trudy Nauchno-issledovatel'skogo Instituta Geologii [The work of the Research Institute of Geology], Voronezh, VSU Publ., vol. 3, 2001, 201 p. (in Russ.).

17. Savko K. A., Samsonov A. V., Holin V. M., Bazikov N. S. Megablock Sarmatia as a fragment of Vaalbar's supercraton: correlation of geological events at the Archean-Paleoproterozoic boundary. Stratigrafiya. Geologicheskaya korrelyaciya, 2017, vol. 25, no 2, pp. 3-26. (in Russ.).

18. Glaznev V. N., Muravina O. M., Voronova T. A., Holin V. M. Ocenka moshchnosti graviaktivnogo sloya zemnoj kory Voronezhskogo kristallicheskogo massiva [Estimation of the thickness of the gravitational layer of the earth's crust of the Voronezh crystalline massif]. Vestnik Voronezhskogo gosudarstvennogo universiteta. Seriya: Geologiya = Proceedings of Voronezh State University. Series: Geology, 2014, no. 4, pp. 78-84. (in Russ.).

19. Voronova T. A., Muravina O. M. Detal'noe plotnostnoe modelirovanie verhnej chasti Voronezhskogo kristallicheskogo massiva [Detailed density modeling of the upper part of the Voronezh crystalline massif]. Vestnik Voronezhskogo gosudarstvennogo universiteta. Seriya: Geologiya = Proceedings of Voronezh State University. Series: Geology, 2014, no. 2, pp. 150-154. (in Russ.). 20. Muravina O. M. Density model of the earth's crust of the Voronezh crystalline massif. Vestnik Voronezhskogo gosudarstvennogo universiteta. Seriya: Geologiya = Proceedings of Voronezh State University. Series: Geology, 2016, no. 1, pp. 108-114. (in Russ.).

21. Minc M. V., Glaznev V. N., Muravina O. M. Deep structure of the crust in the southeast of the Voronezh crystalline massif according to geophysical data: geodynamic evolution in the Paleoproterozoic and the current state of the crust. Vestnik Voronezhskogo gosudarstvennogo universiteta. Seriya: Geologiya $=$ Proceedings of Voronezh State University. Series: Geology, 2017 , no. 4 , pp. 5 - 23. (in Russ.).

22. Glaznev V. N., Zhavoronkin V. I., Muravina O. M., Antonova I. Yu., Voronova T. A., Chereshinskij A. V., Holin P. V. The structure of the upper crust of the Eletsky area of the Losev- 
sky terrane (Voronezh crystalline massif) according to the data of density modeling. Vestnik Voronezhskogo gosudarstvennogo universiteta. Seriya: Geologiya = Proceedings of Voronezh State University. Series: Geology, 2019, no. 3, pp. 74 - 83. (in Russ.). DOI: https://doi.org/10.17308/geology.2019.3/1815

23. Voronova T. A., Glaznev V. N., Muravina O. M., Antonova
I. Yu. The Density Model of the Crystalline Crust the Southwestern Part of the Lipetsk Region. Springer Proceedings in Earth and Environmental Sciences: Practical and Theoretical Aspects of Geological Interpretation of Gravitational, Magnetic and Electric Fields. Eds. D.Nurgaliev, N.Khairullina. Springer Nature Switzerland AG, 2019, pp. 69-76.
Муравина Ольга Михайловна - д. тех. н., профессор, Воронежский государственный университет, Воронеж, Российская Федерация; E-mail: muravina@geol.vsu.ru; ORCID 0000-0003-4772-0825

Жаворонкин Валерий Иванович - к. г.-м. н., доцент, Воронежский государственный университет, Воронеж, Российская Федерация; E-mail: zhavoronkin@geol.vsu.ru; ORCID 0000-0003-0648-4117

Авторы прочитали и одобрили окончательный вариант рукописи.
Olga M. Muravina - Dr.habil. in Techn., Professor, Voronezh State University, Voronezh, Russian Federation;

E-mail: muravina@geol.vsu.ru;

ORCID 0000-0003-4772-0825

Valery I. Zhavoronkin - PhD in Geol-Min., associate professor, Voronezh State University, Voronezh, Russian Federation;

E-mail: zhavoronkin@geol.vsu.ru;

ORCID 0000-0003-0648-4117

The authors have read and approved the final manuscript. 